\title{
Regulation of a Potassium Conductance in Rat Midbrain Dopamine Neurons by Intracellular Adenosine Triphosphate (ATP) and the Sulfonylureas Tolbutamide and Glibenclamide
}

\author{
Ian M. Stanford and Michael G. Lacey \\ Department of Pharmacology, The Medical School, University of Birmingham, Edgbaston, Birmingham B15 2TT, \\ United Kingdom
}

The presence of adenosine triphosphate-regulated potassium channels (K-ATPs) in midbrain dopamine neurons is currently in dispute. This was investigated using whole-cell patch-clamp recordings from dopamine neurons in slices of midbrain from 9-12-d-old rats. Intracellular dialysis with $\mathrm{Mg}^{2+}$ ATP-free solutions resulted in a membrane hyperpolarization (14 $\pm 6 \mathrm{mV}$ ), or outward current (102 $\pm 27 \mathrm{pA})$ in voltage clamp, which developed over $14 \pm 1.6 \mathrm{~min}$. These hyperpolarizations and outward currents were reversed by the K-ATP-blocking sulfonylureas tolbutamide $(100 \mu \mathrm{M})$ and glibenclamide $(3 \mu \mathrm{M})$. This sulfonylurea-sensitive outward current was associated with an increase in a nonrectifying (between -50 and $-130 \mathrm{mV}$ ) conductance of approximately $2 \mathrm{nS}$, with a reversal potential of $-100 \mathrm{mV}$ (in $2.5 \mathrm{~mm}$ extracellular potassium), consistent with a potassium conductance increase. When the dialyzate contained $\mathrm{Mg}^{2+}$ ATP (2 $\mathrm{mm}$ ), no slowly developing hyperpolarization or outward current occurred, and tolbutamide (200 $\mu \mathrm{M})$ and glibenclamide $(10 \mu \mathrm{M})$ did not affect membrane potential or current. Additionally, the "potassium channel activators" (KCAs) lemakalim (200 $\mu \mathrm{M})$ and pinacidil (50 $\mu \mathrm{M})$ were also without effect on the membrane potentlal or holding current in these cells. The hyperpolarizations and outward currents caused by baclofen and quinpirole, agonists at $G A B A_{B}$ and $D_{2}$ receptors, respectively, were neither blocked by sulfonylureas nor occluded by the current resulting from depletion of intracellular ATP. Thus, these K-ATPs appear independent of the potassium channels coupled to $G A B A_{B}$ and $D_{2}$ receptors in these cells. This ATP-regulated potassium conductance may constitute a protective mechanism during anoxia or hypoglycemia, by restricting membrane depolarization of dopamine neurons when intracellular ATP levels fall.

[Key words: adenosine triphosphate, K-ATP channels, potassium channels, ATP-regulated potassium conductance, potassium conductances, dopamine neurons, rat, substantia nigra pars compacta, brain slices, whole-cell recording, patch-clamp recording, intracellular dialysis, GA-

\footnotetext{
Received Oct. 18, 1994; revised Nov. 29, 1994; accepted Dec. 5, 1994.

We thank Drs. Jenni Harvey and Cally Rick for their appraisal of the manuscript, and the Wellcome Trust for their support.

Correspondence should be addressed to Dr. Michael G. Lacey, Department of Pharmacology, The Medical School, University of Birmingham, Vincent Drive, Edgbaston, Birmingham B15 2TT, UK.

Copyright (C 1995 Society for Neuroscience $0270-6474 / 95 / 154651-07 \$ 05.00 / 0$
}

$B A_{B}$ receptors, $D_{2}$ receptors, sulfonylureas, glibenclamide, tolbutamide, Iemakalim, pinacidil]

Potassium channels that open on reduction of intracellular adenosine triphosphate (ATP) concentrations have been demonstrated in a variety of excitable cell types, including cardiac, smooth, and skeletal muscle, pancreatic $\beta$ cells, and neurons (for review, see $\Lambda$ shcroft and $\Lambda$ shcroft, 1990; Edwards and Weston, 1993). Antidiabetic drugs of the sulfonylurea class can block these ATP-regulated potassium (K-ATP) channels, whereas a chemically diverse group of compounds, known collectively as "potassium channel activators" (KCAs), may open them (Edwards and Weston, 1993), although this has not been demonstrated directly and convincingly in single neurons. It seems likely that $\mathrm{K}$-ATP channels are heterogeneous, in terms of both their singlechannel properties and their pharmacology (Ashcroft and Ashcroft, 1990; Fdwards and Weston, 1993). Moreover, the selective targeting of neuronal K-ATP channels with KCAs could have therapeutic benefit to limit damage in both stroke and epilepsy (Miller, 1990).

The substantia nigra (SN) exhibits the densest binding of the sulfonylurea ${ }^{3} \mathrm{H}$-glibenclamide in brain (Mourre et al., 1989) and has been the subject of several studies of K-ATP channel function. Apart from a recent description of single K-ATP channels in presumed SN pars reticulata neurons (Schwanstecher and Panten, 1993), electrophysiological studies of K-ATP channels in the SN have focused upon the dopamine-containing neurons of the substantia nigra pars compacta (SNc). Preliminary reports from Röper and colleagues, using both whole-cell "perforated patch" clamp and single-channel recording from enzymatically isolated cells of adult guinca pig $\mathrm{SN}$, suggested that dopaminc cells possessed potassium channels that opened when extracellular glucose was removed or, in inside-out patches, when intracellular ATP was removed, and could be closed by the sulfonylurea tolbutamide (Röper et al., 1990a,b). Furthermore, the hyperpolarization caused by both dopamine and baclofen was reported to be blocked by tolbutamide (Röper et al., 1990c), suggesting that the K-ATPs and the potassium channels gated by $\mathrm{GABA}_{\mathrm{B}}$ and $\mathrm{D}_{2}$ receptors (Lacey et al., 1988) were one and the same. Another whole-cell patch-clamp study on dissociated rat $\mathrm{SN}$ neurons reported that dopamine neurons were hyperpolarized following dialysis with an intracellular solution containing no added ATP (but not with $2 \mathrm{mM}$ ATP), and also by application of high concentrations of the KCAs cromakalim and pinacidil. Both these effects were antagonized by the sulfonylurea glibenclamide (Häusser et al., 1991). 
This set of observations on dopamine neurons has subsequently been challenged on several fronts by other workers using brain slice preparations, as opposed to acutely isolated cells. Thus, neither the hyperpolarization by dopamine of rat dopamine neurons (recorded with the whole-cell patch-clamp method in brain slices) was found to be sensitive to either tolbutamide or glibenclamide, nor was cromakalim found to cause a hyperpolarization (Hicks and Henderson, 1992). Guinea pig SN neurons with the characteristics of dopamine neurons (recorded intracellularly with sharp microelectrodes in brain slices) were largely unaffected by anoxic conditions, which would be expected to lower intracellular ATP levels (Murphy and Greenfield, 1992). However, in another study, rat dopamine neurons, also studied with sharp microelectrodes in slices, were hyperpolarized by anoxia, but the increased potassium conductance responsible was insensitive to glibenclamide (Mercuri et al., 1994). In view of these contradictions, we sought to establish whether functional $\mathrm{K}$-ATP channels were indeed present in dopamine neurons in brain slices.

Some of these results have been reported in abstract form (Stanford and Lacey, 1993).

\section{Materials and Methods}

Brain slice preparation and recording techniques. Whole-cell patchclamp recordings from cells in $\mathrm{SNc}$ were made from parasagittal slices (200 $\mu \mathrm{m}$ thick) of male Wistar rat (9-12 d old) midbrain. Brain slices were prepared as previously described for coronal slices (Lacey et al., 1989 ) and, once transferred to a recording chamber (volume, $0.75 \mathrm{ml}$ ), were continuously superfused at $2 \mathrm{ml} / \mathrm{min}$ in a bicarbonate-buffered medium ( $\mathrm{pH} 7.2)$ containing (mM) $\mathrm{NaCl}(126), \mathrm{KCl}(2.5), \mathrm{NaH}_{2} \mathrm{PO}_{4}$ (1.2), $\mathrm{MgCl}_{2}$ (1.3), and $\mathrm{CaCl}_{2}(2.4)$ and maintained at $33-35^{\circ} \mathrm{C}$. $\mathrm{Re}$ cordings were made with borosilicate glass pipettes of resistance of 3 $5 \mathrm{M} \Omega$ containing (mM) K-gluconate (125), $\mathrm{MgCl}_{2}(2), \mathrm{CaCl}_{2}(1), \mathrm{NaCl}$ (10), 1,2-bis(2-aminophenoxy)ethane- $N, N, N^{\prime}, N^{\prime}$-tetraacetic acid (BAPTA; 10), $N$-(2-hydroxyethyl)-piperazine- $N^{\prime}$-2-ethanesulfonic acid (HEPES; 10), and GTP $(0.3)$, buffered to $\mathrm{pH} 7.25$ with $\mathrm{KOH}(\sim 40 \mathrm{~mm})$. Intracellular adenosine triphosphate (magnesium salt; $\mathrm{Mg}^{2+} \mathrm{ATP}$ ) concentrations were either 0 or $2 \mathrm{~mm}$. The pars compacta of the substantia nigra could be visualized under low-power magnification, and individual neurons observed before and during recording using a Nomarski optical system comprising a $40 \times$ water immersion objective with a fixed stage, noninverted, Zeiss Axioskop 50 microscope (Oberkochen, Germany; see Fig. 1). Pipettes were advanced through the slice under visual control toward a single neuron, with their contents under positive pressure. A tight seal was made by applying negative pressure until resistances on the order of $10-20 \mathrm{G} \Omega$ were obtained. The membrane was then ruptured by suction and membrane potential and current measured using an Axopatch 1B patch-clamp amplifier (Axon Instruments, Foster City, CA). Whole-cell access resistance of all cells used in this study was in the range of 10-30 $\mathrm{M} \Omega$; amplifier compensation of 70 $80 \%$ effectively reduced this value electronically to $<10 \mathrm{M} \Omega$. Thus, in measuring a $500 \mathrm{pA}$ current the voltage error due to access resistance would be expected to be no more than $5 \mathrm{mV}$. After initial determination and compensation, access resistance was monitored by measuring the size of the capacitance transient in response to a $5 \mathrm{mV}$ depolarizing step (Stuart et al., 1993). Experiments were abandoned if this changed by more than $10 \%$ during recording. Membrane current and voltage recordings were amplified and displayed on a chart recorder and, when evoked by voltage step protocols generated by pCLAMP software (Axon Instruments, Foster City, CA), stored on an Elonex PC-450 computer (Bradford, UK) for subsequent analysis and display.

Drugs used. Drugs were applied in the superfusate by changing to a solution differing only in content by the addition of a known concentration of drug, with exchange beginning after a dead time of around 20-30 sec. Drugs used were quinpirole (Sigma), baclofen (Sigma), tolbutamide (Sigma; dilutions from $0.5 \mathrm{M}$ stock solution in dimethyl sulfoxide), pinacidil (Research Biochemicals International, Natick, MA; $0.25 \mathrm{M}$ stock in $70 \%$ ethanol), glibenclamide $(0.1 \mathrm{M}$ stock in dimethyl sulfoxide), and lemakalim [(-)-cromakalim; $0.4 \mathrm{~m}$ stock in $50 \%$ di-

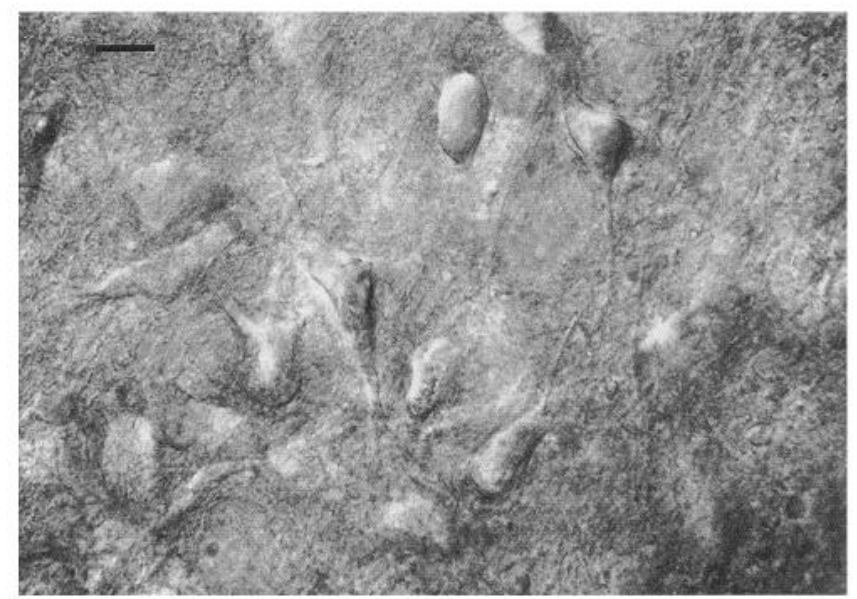

Figure 1. Photomicrograph showing neurons within the substantia nigra pars compacta visualized in situ in the recording chamber using a Nomarski optical system $(40 \times$ water immersion objective with a Zeiss Axioskop 50 microscope). Scale bar, $20 \mu \mathrm{m}$.

methyl sulfoxide]. Lemakalim and glibenclamide were gifts from Dr. Hugh Herdon, SmithKline Beecham Ltd., Harlow, UK.

All numerical data are expressed as mean \pm standard deviation unless otherwise stated.

\section{Results}

The results of the present study are derived from recordings from $38 \mathrm{SNc}$ neurons. These cells were all $20-40 \mu \mathrm{m}$ along their longest axis and usually found in close proximity to others of similar size in SNc (Fig. 1). They exhibited spontaneous action potential firing at rates of $0.5-6 \mathrm{~Hz}$ (mean $3.4 \pm 1.1 \mathrm{~Hz}$ ) as measured within $30 \mathrm{sec}$ of establishing whole-cell recording (Fig. 2A). Under voltage clamp, their mean resting potential (at which the holding current was zero) was $-52.6 \pm 3.1 \mathrm{mV}$ and input chord conductance between -60 and $-70 \mathrm{mV}$ was 2.98 $\pm 1.13 \mathrm{nS}$ ( 12 cells). Hyperpolarizing voltage steps from -60 $\mathrm{mV}$ elicited a pronounced time- and voltage-dependent inward current $\left(I_{h}\right)$ in all cells (Fig. 2B), and application of dopamine (30 $\mu \mathrm{M}, 3$ cells) or the $\mathrm{D}_{2}$ receptor agonist quinpirole $(10 \mu \mathrm{M}$, 7 cells) caused a reduction in firing rate, accompanied by a hyperpolarization, which was reversible on washout of the drug (Fig. 2A). All these properties correspond to those of dopaminecontaining SN neurons demonstrated in previous studies (Grace and Onn, 1989; Yung et al., 1991), and to those of cells presumed to be dopamine-containing in other studies (such as Lacey et al., 1989; Röper et al., 1990c; Johnson and North, 1992; see Lacey, 1993, for review). Thus, the cells studied here are considered to be dopamine neurons.

\section{Outward currents develop during intracellular dialysis with ATP-free solution: sensitivity to sulfonylureas}

Recordings were made from 30 cells with pipettes that contained no added $\mathrm{Mg}^{2+}$ ATP. Twenty-eight of these cells exhibited a slowly developing and sustained membrane hyperpolarization that was accompanied by a cessation of firing (Fig. $3 A$ ) or (in voltage clamp) production of outward current (Fig. 3B). The onset of the developing membrane hyperpolarization or outward current was evident within around 4 min of the commencement of whole-cell recording following membrane breakthrough and cytoplasmic access (mean of $3.2 \pm 1.6 \mathrm{~min}$ in 16 cells; Fig. $3 A, B)$. The membrane current or potential reached a new steady 
$\mathbf{A}$

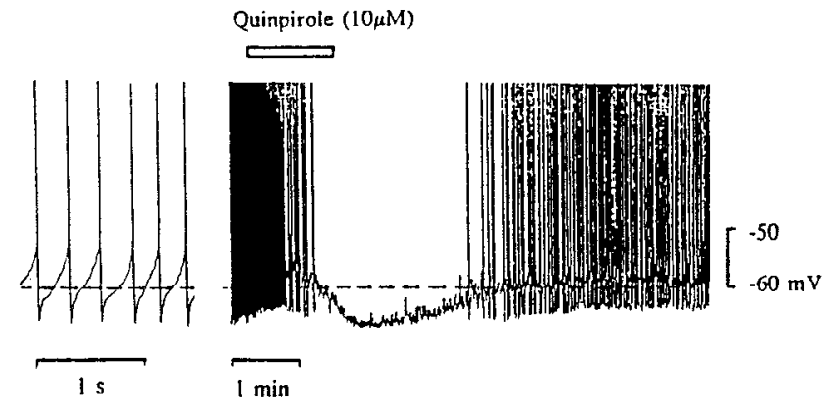

B

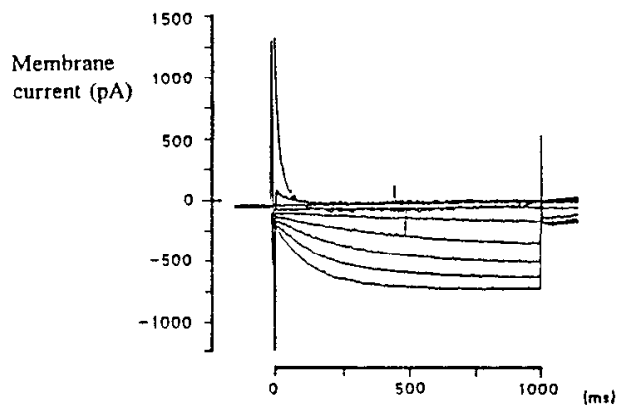

Figure 2. Electrophysiological characteristics of dopamine neurons in the substantia nigra pars compacta, recorded with whole-cell patchclamp method using pipcttes containing $\mathrm{Mg}^{2+}$ ATP ( $2 \mathrm{mM}$ ). A, Currentclamp recording from a dopamine neuron at rest, firing action potentials (full amplitude not shown) in a "pacemaker-like" manner at $4.2 \mathrm{~Hz}$. Action potentials show pronounced afterhyperpolarizations. Quinpirole $(10 \mu \mathrm{M})$, applied for the period indicated by the bar, caused an inhibition of spontaneous action potential firing, accompanied by a membrane hyperpolarization, which reversed on washout. The early part of the record is displayed with a faster time scale. $B, A$ series of membrane currents (superimposed for ease of comparison), recorded under voltage clamp, during a series of voltage steps ( $1 \mathrm{sec}$ duration) to potentials in the range of -40 to $-120 \mathrm{mV}$ (in $10 \mathrm{mV}$ increments) from a holding potential of $-60 \mathrm{mV}$. Note time- and voltage-dependent inward currents $\left(I_{h}\right)$ activated upon increasing hyperpolarization. Both fast and slow inward currents are evoked by depolarizing steps.

state value within 6-25 min of commencing whole-cell recording (mean of $13.9 \pm 1.6 \mathrm{~min}, 14$ cells; Fig. $3 A, B$ ). At this new steady state level, the outward current that developed was 102.5 $\pm 27.0 \mathrm{pA}(8$ cells) and the hyperpolarization $13.6 \pm 5.7 \mathrm{mV}$ (6 cells).

Both the outward currents and membrane hyperpolarizations resulting from intracellular dialysis with ATP-free solutions were reversed by application of either tolbutamide (100 $\mu \mathrm{M} ; 13$ of 14 cells tested) or glibenclamide ( $3 \mu \mathrm{M}$; all 5 cells tested; see Fig. $3 A, B)$. This effect of tolbutamide reversed within around $10 \mathrm{~min}$ of its removal from the perfusing solution, whereas that of glibenclamide was irreversible, even when washed from the tissue for up to $40 \mathrm{~min}$.

In recordings from a further eight cells using pipettes that contained $\mathrm{Mg}^{2+}$ ATP ( $2 \mathrm{mM}$ ), no changes in either action potential firing rate (in current-clamp recordings) or membrane current (mcasurcd under voltage clamp at $-60 \mathrm{mV}$ ) were observed for up to $20 \mathrm{~min}$ after initiation of whole-cell recording (Fig. 3C). Furthermore, in these same cells, neither tolbutamide $(200 \mu \mathrm{M}$; 6 cells) nor glibenclamide $(10 \mu \mathrm{M} ; 2$ cells) caused any detectable effect on either firing rate or, under voltage clamp, membrane current (Fig. 3D). Thus, intracellular dialysis with $\mathrm{Mg}^{2+} \mathrm{ATP}$ free solution resulted in a sulfonylurea-sensitive hyperpolariza- tion or outward current that was not evident in cells loaded with $\mathrm{Mg}^{2+}$ ATP (2 mM).

\section{Dialysis with ATP-free solution increases potassium conductance}

In each of 10 cells recorded using pipettes containing no added $\mathrm{Mg}^{2+} \mathrm{ATP}$, current/voltage relationships were obtained within 2 min of commencing whole-cell recording (immediately after determination of series resistance and the appropriate compensation). This was done in voltage clamp at a holding potential of $-60 \mathrm{mV}$, using a series of voltage steps (multiples of $10 \mathrm{mV}$, $200 \mathrm{msec}$ duration, $0.1 \mathrm{~Hz}$ ) to command potentials in the range -50 to $-130 \mathrm{mV}$, such as shown in Figure $4 A$. As dialysis progressed, an outward current at the holding potential of -60 $\mathrm{mV}$ was observed. Once the membrane current had stabilized at a new level (after $\sim 15 \mathrm{~min}$ ), the same series of voltage steps was repeatcd. Either tolbutamide $(100 \mu \mathrm{M} ; 5$ cells) or glibenclamide ( $3 \mu \mathrm{M} ; 3$ cells) was then applied, reversing the outward current that had developed during the dialysis period, and the currents resulting from the same series of voltage steps were once more obtained (Fig. 4A).

Current/voltage relationships for each cell were constructed for each of the three sets of currents evoked by the voltage step protocol. Membrane currents were measured within 20-30 msec of onset of the voltage step (the same time point was used for all currents from any given cell, and selected to permit settling of the capacitance transient, but not onset of $I_{h}$ activation), thus obtaining essentially a measure of leak (or "instantaneous"), rather than steady-state, membrane conductance. The outward current caused by intracellular dialysis with ATP-free solution was associated with a conductance increase (Fig. $4 B$ ). The potential at which this current reversed polarity with respect to the membrane current at the start of dialysis was $-95.7 \pm 9.4 \mathrm{mV}$ (10 cells), and with respect to that after application of either tolbutamide or glibenclamide was $-99.9 \pm 6.13 \mathrm{mV}$ (8 cells). These two values were not significantly different from each other $(p>0.1, t$ test). The reversal potential of the sulfonylureasensitive currents $(-99.9 \pm 6.13 \mathrm{mV})$ was not signiticantly ditferent from the estimated equilibrium potential for potassium ions $(-105 \mathrm{mV}$ under these experimental conditions; $p>0.05)$, indicating that this current was carried by potassium ions. However, the mean reversal potential of the currents caused by dialysis with ATP-free solution $(-95.7 \pm 9.4 \mathrm{mV})$ was significantly different from $-105 \mathrm{mV}(p<0.002)$, raising the possibility that the dialysis caused an additional, sulfonylurea-insensitive, inward current. Nonetheless, the proximity of these values to ${ }^{--} 105 \mathrm{mV}$ indicates that the principal charge carrier for both these currents was potassium ions.

The currents activated by dialysis with ATP-free solution, and those blocked by sulfonylurea application following such dialysis (calculated by the respective subtraction of the predialysis currents, or the currents in the presence of sulfonylurea, from the post dialysis currents), were pooled and plotted against membrane potential (Fig. 4C). Expressed in this way, the outward current developed with dialysis with ATP-free solution had a reversal potential of $-94 \mathrm{mV}$, and that blocked by the sulfony lureas following the dialysis had a reversal potential of -100 $\mathrm{mV}$ (Fig. 4C). The conductance of both these currents appeared linear in the voltage range examined $(-50$ to $-130 \mathrm{mV})$, with mean slope values of $1.95 \pm 0.83 \mathrm{nS}$ (sulfonylurea current, 8 cells) and $2.2 \pm 1.4 \mathrm{nS}$ (dialysis current, 10 cells). The clear lack of a significant difference between these two conductances 
ATP-free pipette solution

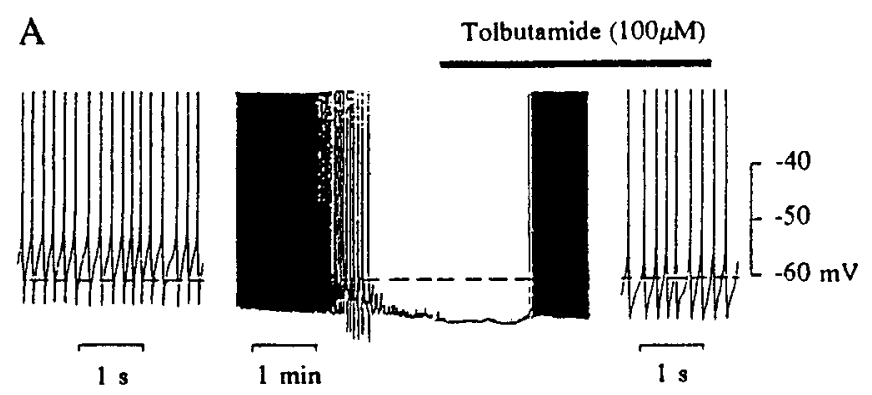

$\mathrm{C}$

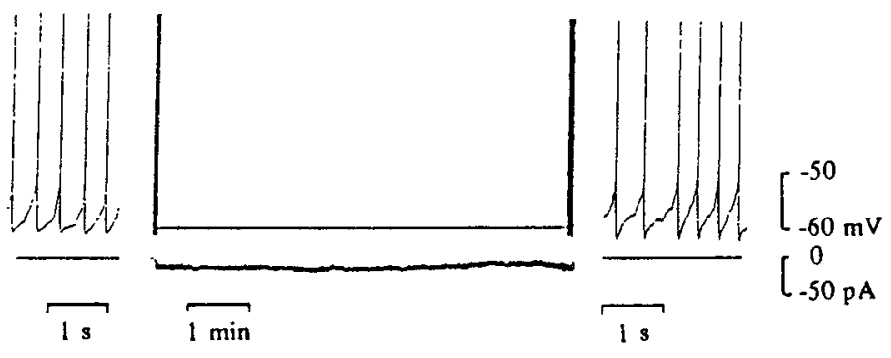

$\mathrm{D}$

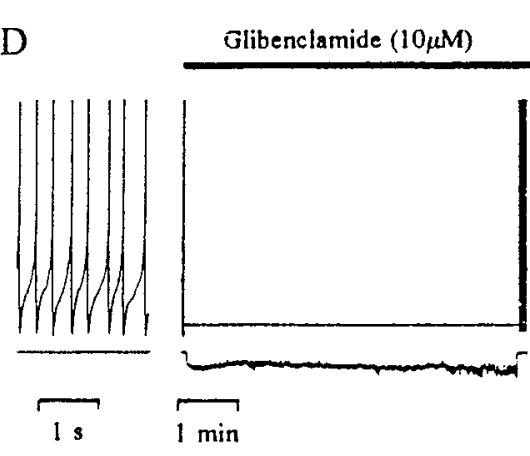

D

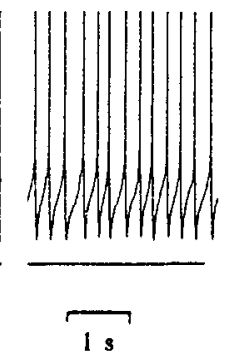

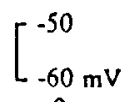

$\left[\begin{array}{cc}0 \\ -100\end{array}\right.$
2 mM ATP in pipette

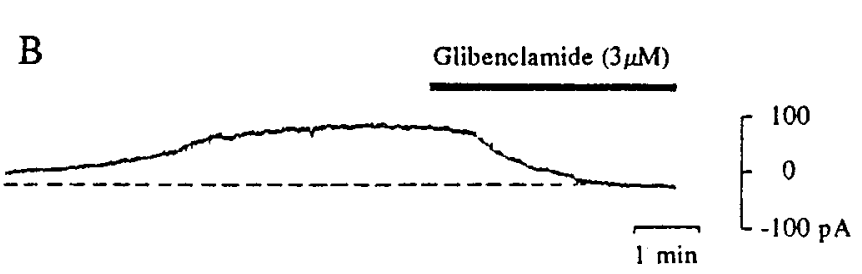

Figure 3. Dialysis of cells with a pipette solution containing no added $\mathrm{Mg}^{2+} \mathrm{ATP}(A$ and $B)$ caused a membrane hyperpolarization or an outward current that was blocked by sulfonylureas. This was not seen when $\mathrm{Mg}^{2+} \mathrm{ATP}(2 \mathrm{~mm})$ was included in the pipette solution $(C$ and $D)$. $A$ and $B$, Rccords of resting membrane potential $(A)$, or membrane current at $60 \mathrm{mV}(B)$, from two different dopamine neurons commencing within 1 min of obtaining whole-cell access with a pipette containing no added $\mathrm{Mg}^{2+}$ ATP. $A$, Within 4 min of whole-cell recording, spontaneous firing rate had ceased, accompanied by a membrane hyperpolarization to $-68 \mathrm{mV}$ that was reversed by tolbutamide (100 $\mu \mathrm{M}$; solid bar). $B$, The slowly developing outward current of $108 \mathrm{pA}$ was completely abolished by subsequent application of glibenclamide $(3 \mu \mathrm{M}$, solid bar). $C$ and $D$, Records of both membrane potential (upper) and membrane current (lower) from two different cells, both recorded with pipettes containing $\mathrm{Mg}^{2+} \mathrm{ATP}$ ( 2 mM). Records start within 2 min after gaining whole-cell access and show initially, under current-clamp conditions, the cells at rest, firing spontaneous action potentials. Membrane voltage was then clamped at $-60 \mathrm{mV}$ and membrane current monitored (middle section of records). No change in holding current or firing rate was observed over the $11 \mathrm{~min}(C)$ or $7 \mathrm{~min}(D)$ shown and, in $D$, glibenclamide $(10 \mu \mathrm{M}$; solid bar) was also without effect on these variables.

$(p>0.5)$ strongly indicates that the same sets of channels ar involved, and that the potassium conductance increased by depletion of intracellular ATP is the same as that blocked by tolbutamide and glibenclamide under these conditions. In summary, the outward current seen following reduction of intracellular ATP concentrations, the likelihood that it is due to an increase in potassium conductance, and its sensitivity to sulfonylureas, all argue for the presence of functional K-ATP channels on dopamine neurons.

\section{Lack of effect of potassium channel activators lemakalim and pinacidil}

The "potassium channel activators" (KCAs) lemakalim (200 $\mu \mathrm{M})$ and pinacidil $(50 \mu \mathrm{M})$ were applied for $4-8 \mathrm{~min}$ to eight cells (four in each case) following at least $15 \mathrm{~min}$ of whole-cell recording with pipettes containing $\mathrm{Mg}^{2+} \mathrm{ATP}$ ( $2 \mathrm{mM}$ ). No effect on resting membranc potcntial, firing ratc, or membrane current in voltage clamp at $-60 \mathrm{mV}$ was observed in response to either substance.

The potassium conductance coupled to $D_{2}$ and $G A B A_{B}$ receptors is distinct from the sulfonylurea-sensitive, ATP-regulated potassium conductance

The $\mathrm{GABA}_{\mathrm{B}}$ agonist bacloren $(3 \mu \mathrm{M})$ was applied to three cells, all recorded with $\mathrm{Mg}^{2+} \mathrm{ATP}(2 \mathrm{mM})$ in the pipette, causing in each case a cessation of action potential firing accompanied by a pronounced membrane hyperpolarization or outward current that was not reduced by glibenclamide ( $10 \mu \mathrm{M}, 3$ cells; Fig. $5 A$ ). In other cells that had developed an outward current due to dialysis with an ATP-free pipette solution, baclofen ( $3 \mu \mathrm{M} ; 6$ cells) and the $D_{2}$ receptor agonist quinpirole ( $10 \mu \mathrm{M} ; 2$ cells) were able to produce an additional outward current. This additional current, seen when a supramaximal concentration of baclofen $(30 \mu \mathrm{M})$ was used, was comparable to that seen following block of the dialysis current with tolbutamide (200 $\mu$ m; Fig. $5 B)$. Such additivity indicates that the potassium channels coupled to $D_{2}$ and $\mathrm{GABA}_{\mathrm{B}}$ receptors in these cells are indeed distinct from the K-ATP channels; otherwise, the current activated by depleting intracellular ATP would be expected to occlude that activated by bacloten.

\section{Discussion}

The ATP-regulated potassium conductance

Dialysis of cells with ATP-free solutions led to a slowly developing hyperpolarization (accompanied by cessation of spike firing) or outward current that was not seen in cells recorded with pipettes containing $\mathrm{Mg}^{2+} \mathrm{ATP}$ ( $2 \mathrm{mM}$ ). These phenomena were blocked by the sulfonylureas tolbutamide and glibenclamide. However, the sulfonylureas were without effect on cells dialyzed with $\mathrm{Mg}^{2+}$ ATP (2 mM; Fig. 3). The outward current caused by 

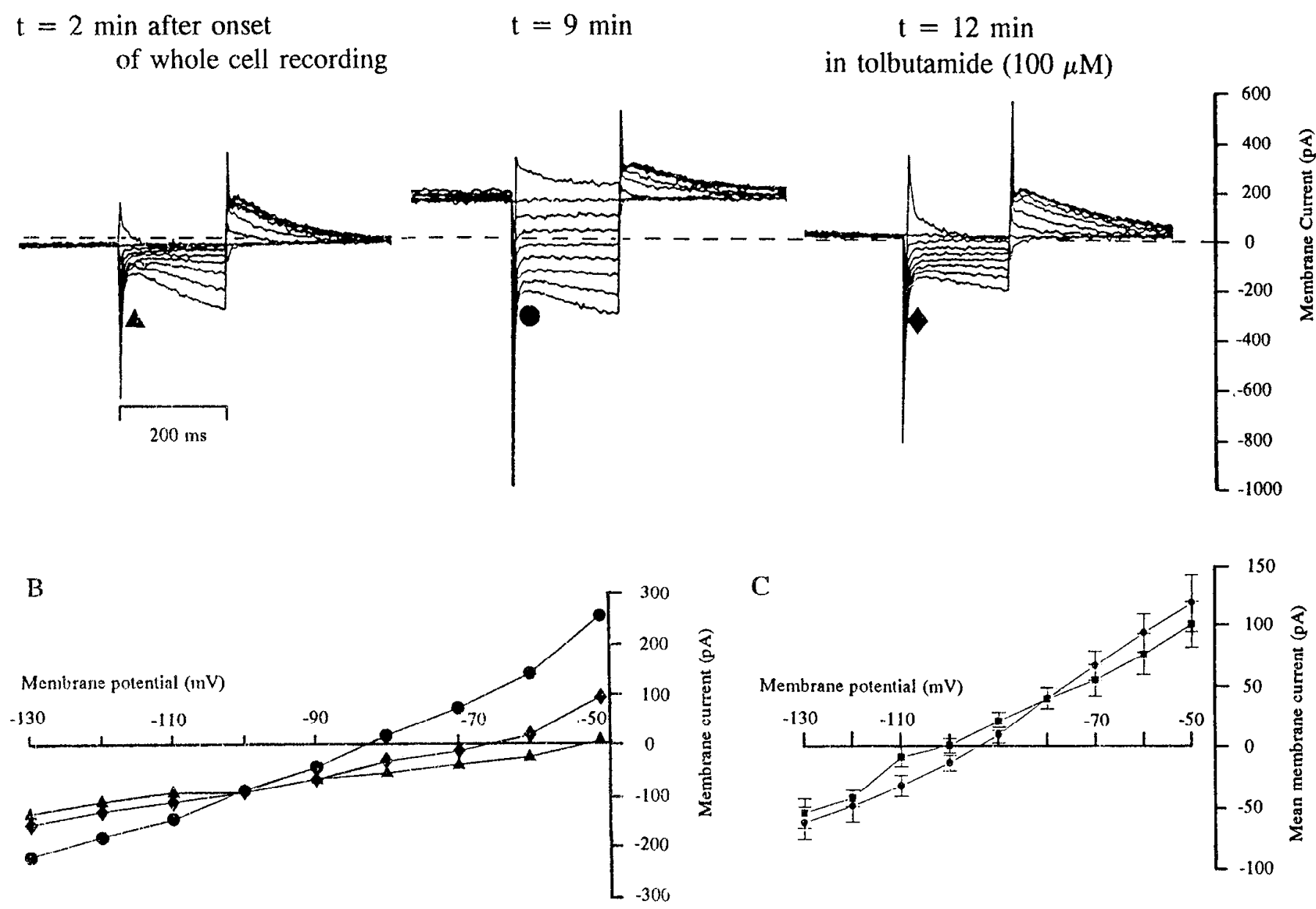

Figure 4. Intracellular dialysis with $\mathrm{Mg}^{2+} \mathrm{ATP}-$ free solution increased a sulfonylurea-sensitive potassium conductance. A, Three sets of records from the same cell, each comprising nine superimposed current records produced by a series of voltage steps ( $200 \mathrm{msec}$ duration) to potentials in the range of -50 to $-130 \mathrm{mV}$ (in $10 \mathrm{mV}$ increments) from a holding potential of $-60 \mathrm{mV}$. Recording was made with a pipette containing a $\mathrm{Mg}^{2+}$ ATP-free solution and the current sets recorded at 2,9, and 12 min after onset of whole-cell recording, the last set being in the presence of tolbutamide $(100 \mu \mathrm{M}) . B$, Plot of currents obtained in $A$, measured $24 \mathrm{msec}$ after onset of each voltage step, against membrane potential. The membrane conductance after 9 min of recording (-) was increased compared to that 2 min after onset of dialysis $(\boldsymbol{\Delta})$, with reversal potential at $-100 \mathrm{mV}$. Tolbutamide $(100 \mu \mathrm{M})$ caused a decrease in conductance $(\$)$ with a reversal potential, relative to the conductance prior to tolbutamide addition, of $-100 \mathrm{mV}$. $C$ Pooled data from several such experiments. Points are means of subtracted currents from each cell yielding either the currents developed during dialysis with $\mathrm{Mg}^{2+} \mathrm{ATP}$-free solution $(\mathbf{O}=10$ cells), or the sulfonylurea-sensitive currents following the dialysis [ $\mathbf{\square}$; $n=8$ cells, 3 with glibenclamide $(3 \mu \mathrm{M}), 5$ with tolbutamide $(100 \mu \mathrm{M})]$. The two conductances display similar reversal potentials $(-94$ and -100 mv, respectively) and both are essentially voltage independent between -50 and $-130 \mathrm{mv}$. Error bars represent sem.

intracellular dialysis with ATP-free solution was independent of both time and voltage in the voltage range examined ( -50 to $-130 \mathrm{mV}$ ). This current reversed polarity at around $-94 \mathrm{mV}$ (Fig. 4), which was close to, but significantly different from, the predicted potassium equilibrium potential of $-105 \mathrm{mV}$. However, the reversal potential of the sulfonylurea-sensitive current following dialysis with ATP-free solutions ( $-100 \mathrm{mV}$; Fig. 4) was not significantly different from $-105 \mathrm{mV}$. One possible reason for this discrepancy is that reduction of intracellular ATP in these experiments increased not only a sulfonylurea-sensitive potassium conductance, but also caused an additional, but smaller, sulfonylurea-insensitive, inward current. In the study of Mercuri et al. (1994), the anoxic hyperpolarization (which was not sulfonylurea sensitive) had a reversal potential of around -85 $\mathrm{mV}$ in $2.5 \mathrm{~mm}$ potassium ions. The difference between that value and the predicted potassium equilibrium potential was accounted for by the additional activation by anoxia of inward currents, suggested to reflect disruption of ATP-dependent $\mathrm{Na}^{+}-\mathrm{Ca}^{2+}$ and/ or $\mathrm{Na}^{+} \mathrm{K}^{+}$exchangers (Mercuri et al., 1994). In the present study, however, neither the mean slope value nor the reversal potential of the conductance increased by intracellular ATP depletion differed significantly from those of the sulfonylurea-sensitive conductance, nor did the sulfonylureas uncover any additional inward current caused by dialysis with ATP-free solutions (see Figs. $3 A, B ; 4 ; 5$ ). It is concluded that dialysis with ATP-free solutions had no clear effect other than to increase a sulfonylurea-sensitive potassium conductance. There is a preliminary report that dialysis of acutely dissociated rat dopamine neurons with 0 or $0.3 \mathrm{~mm}$ (but not $25 \mathrm{~mm}$ ) ATP, while causing a tolbutamide-sensitive membrane hyperpolarization, also precipitated a subsequent depolarization after a few minutes of dialysis (Röper and Ashcroft, 1993). This depolarization might 


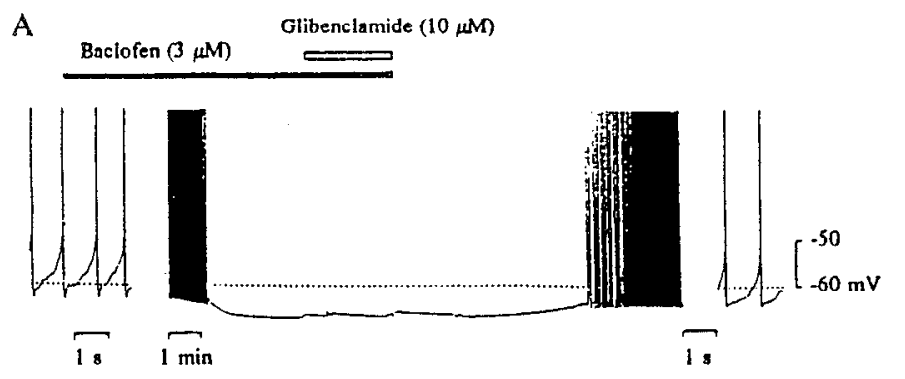

B

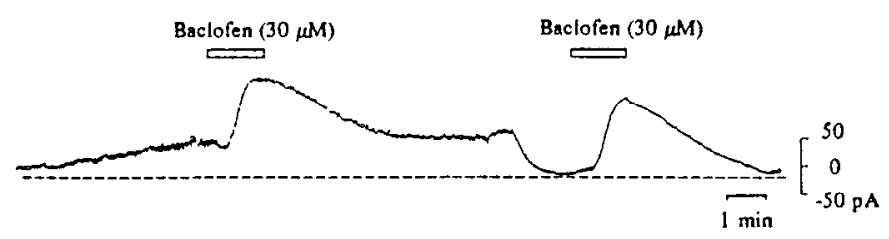

Figure 5. The membrane hyperpolarization and outward current in duced by baclofen were both insensitive to sulfonylureas and independent of the ATP-regulated potassium conductance. $A$, Record of membrane potential from a dopamine neuron firing at a constant rate of 1.2 Hz. Baclofen ( $3 \mu \mathrm{M}$; solid bar) caused a reversible cessation of action potential firing accompanied by a membrane hyperpolarization. Glibenclamide $(10 \mu \mathrm{M}$; open bar) was without effect on the baclofen hyperpolarization. Recording pipette contained $\mathrm{Mg}^{2+} \mathrm{ATP}$ ( $2 \mathrm{~mm}$ ). $B$, Record of membrane current from another cell under voltage clamp at $-60 \mathrm{mV}$, commencing within $1 \mathrm{~min}$ of gaining whole-cell access with a recording pipette containing no added $\mathrm{Mg}^{2+} \mathrm{ATP}$. The initial holding current level was $-18 \mathrm{pA}$ (dashed line). An outward current of $71 \mathrm{pA}$ slowly developed after $7 \mathrm{~min}$ of dialysis. At this point, baclofen $(30 \mu \mathrm{M}$, a supramaximal concentration; open bar) was applied, causing an additional outward current of $121 \mathrm{p} \Lambda$ that reversed on wash. Subsequent appli cation of tolbutamide $(200 \mu \mathrm{M})$ completely abolished the outward current developed during the first $16 \mathrm{~min}$ of recording. In the presence of tolbutamide, baclofen $(30 \mu \mathrm{M})$ caused an outward current or $136 \mathrm{pA}$, comparable to that of $121 \mathrm{pA}$ seen in the absence of tolbutamide. However, this was appreciably less than the $192 \mathrm{pA}$ net current attributable to dialysis with ATP-tree solution and the action of baclofen. I'Tis additivity of the K-ATP and baclofen currents indicates that they utilize a different set of potassium channels.

correspond to that seen during anoxia by Mercuri et al. (1994), and be a consequence of the reduced cytoplasmic volume of acutely dissociated cells. A more extensive intracellular dialysis in isolated cells might more readily initiate K-ATP channel "rundown," due to dephosphorylating conditions (Ashcroft and Ashcroft, 1990; Edwards and Weston, 1993), as well as the disruption of other ATP-dependent processes.

The failure of tolbutamide or glibenclamide to block the action of baclofen or quinpirole confirms and extends the report of Hicks and Henderson (1992), and further questions the principal finding of Röper et al. (1990c). Furthermore, the apparent independence of the outward tolbutamide-sensitive current caused by dialysis with ATP-free solutions and the baclofen outward current (Fig. 5B) is direct evidence that the potassium current regulated by intracellular ATP and that gated by both GA$\mathrm{BA}_{\mathrm{B}}$ and $\mathrm{D}_{2}$ receptors (Lacey et al.; 1988) utilize different sets of channels. Thus, although in several other cell types G-protein-coupled receptors may be able to operate potassium channels gated by intracellular ATP (Zhang et al., 1994; and see Edwards and Weston, 1993, for review), this has yet to be unequivocally demonstrated in dopamine neurons.
The pharmacology of the ATP-regulated potassium conductance

The block by the sulfonylureas tolbutamide $(100 \mu \mathrm{M})$ and glibenclamide $(3 \mu \mathrm{M})$ of the hyperpolarization/outward current resulting from dialysis with ATP-free solution is a characteristic of K-ATPs in ventromedial hypothalamic neurons (Ashford et al., 1990). The effective concentrations were $1-4$ orders of magnitude greater than the affinity of sulfonylureas at the high-affinity binding site for ${ }^{3} \mathrm{H}$-glibenclamide (see Ashcroft and Ashcrott, 1992, for review), suggesting that the site bound by sulfonylureas to block these K-ATPs may not be that labeled with high affinity by ${ }^{3} \mathrm{H}$-glibcnclamide. The failure to demonstrate high-affinity ${ }^{3} \mathrm{H}$-glibenclamide binding sites on rat midbrain dopamine neurons (Hicks et al., 1994) supports this view.

The ineffectiveness of the KCAs lemakalim and pinacidil might be taken to be evidence against the presence of K-ATPs in dopamine neurons. However, while there are several examples of actions of KCAs that may be attributable to actions on K-ATPs on other neuronal types (Ben-Ari el al., 1990; Schmid Antomarchi et al., 1990; Politi and Rogawski, 1991; Zini et al., 1991), none has been shown at single-channel, or even singlecell, level (Sellers et al., 1992). Thus, the failure to demonstrate an action of lemakalim and pinacidil here might indicate that the K-ATPs in dopamine neurons have a different pharmacology to those on other cell types (see Edwards and Weston, 1993, for review). Alternatively, the presence of ATP ( $2 \mathrm{mM}$ ), which might compete with KCAs for the site on the channel through which they effect its closure (for review, see Henry and Escande, 1994), could have prevented them from acting.

Thus, the possibility that certain KCAs may be able to operate the K-ATPs in dopamine neurons cannot be completely ruled out.

\section{ATP-regulated potassium channels in dopamine neurons: functional significance}

The present study was carried out solely on cells exhibiting the characteristics of the dopamine-containing neurons of ventral midbrain (reviewed in Lacey, 1993). Establishing this was important for the interpretation of the present findings in the context of previous work by others, and also on the functional significance of the results. It has been reported that anoxia either had no effect on dopamine neurons recorded intracellularly in brain slices (Murphy and Greenfield, 1992), or caused a hyperpolarization that was glibenclamide insensitive (Mercuri et al., 1994). Our observations suggest that under conditions such as anoxia, where intracellular ATP levels are likely to fall, sulfonylurea-sensitive potassium channels would be expected to be activated. Indeed, anoxia has been shown to activate sulfonylurea-sensitive potassium channels in acutely dissociated rat dopamine neurons (Jiang et al., 1994). However, as these observations, as well as our own, were made on rats aged 9-20 d, it is conceivable that developmental changes, or some other events during experimental anoxia in adult brain slice preparations, may serve to obscure the consequence of the increased conductance through $\mathrm{K}-\Lambda \mathrm{TPS}$.

The high-affinity ${ }^{3} \mathrm{H}$-glibenclamide binding site in substantia nigra appeared insensitive to 6-hydroxydopamine lesions, which reduced considerably the numbers of dopamine neurons (Hicks et al., 1994). As indicated above, reconciliation of this with our demonstration of the effectiveness of glibenclamide may be that the high-affinity ${ }^{3} \mathrm{H}$-glibenclamide binding site is distinct from 
that through which sulfonylurcas, including glibenclamide, block this ATP-regulated potassium conductance. Its role may be in mediating other sulfonylurea-sensitive actions attributable to K-ATP channels on nondopamine neurons SN (Amoroso et al., 1990; Schmid Antomarchi et al., 1990; Schwanstecher and Panten, 1993).

Dopamine neurons play a well-established role in both locomotion and locomotor drive (Fibiger and Phillips, 1986) and in voluntary movement (Schultz, 1982). Inactivation of dopamine neurons via an ATP-regulated potassium conductance might be an appropriate response to hypoglycemia or anoxia insofar as cessation of locomotion will reduce energy demand. Furthermore, activation of K-ATPs might be expected to play a neuroprotective role through reducing metabolic demand in individual cells by reducing action potential firing rate. Opening of $\mathrm{K}$-ATPs would also render depolarization less likely (as a consequence of glutamate release, e.g.) and ensuing calcium entry via voltage-dependent channels, which would also have neuroprotective benefit (Choi, 1988). As the loss of dopamine neurons would be a profoundly disabling consequence of their metabolic dysfunction, resulting in the ataxia associated with Parkinson's Disease, the ATP-regulated potassium conductance in dopamine neurons represents a potential safeguard against their damage by acute hypoxic or hypoglycemic insult.

\section{References}

Amoroso S, Schmid Antomarchi H, Fosset M, Lazdunski M (1990) Glucose, sulfonylureas, and neurotransmitter release: role of ATPsensitive $\mathrm{K}^{+}$channels. Science 247:852-854.

Ashcroft SJ, Ashcroft FM (1990) Properties and functions of ATPsensitive K-channels. Cell Signal 2:197-214.

Ashcroft SJH, Ashcroft FM (1992) The sulfonylurea receptor. Biochem Biophys Act 1175:45-49.

Ashford MLJ, Boden PR, Treherne JM (1990) Tolbutamide excites rat glucoreceptive ventromedial hypothalamic neurones by indirect inhibition of ATP-K ${ }^{+}$channels. Br J Pharmacol 101:531-540.

Ben-Ari Y, Krnjevic K, Crepel V (1990) Activators of ATP-sensitive $\mathrm{K}^{+}$channels reduce anoxic depolarization in CA3 hippocampal neurons. Neuroscience 37:55-60.

Choi DW (1988) Glutamate neurotoxicity and diseases of the nervous system. Neuron 1:623-634.

Edwards G, Weston AH (1993) The pharmacology of ATP-sensitive potassium channels. Annu Rev Pharmacol Toxicol 33:597-637.

Fibiger HC, Phillips AG (1986) Reward, motivation, cognition: psychobiology of mesentelencephalic dopamine systems. In: Handbook of physiology, Sect 1, The nervous system, Vol IV, Intrinsic regulatory systems of the brain (Mountcastle VB, Bloom FE, eds), pp 647675. Bethesda, MD: American Physiological Socicty.

Grace AA, Onn SP (1989) Morphology and electrophysiological properties of immunohistochemically-identified rat dopamine neurons recorded in vitro. J Neurosci 9:3463-3481.

Häusser MA, de Weille JR, Lazdunski M (1991) Activation by cromakalim of pre- and post-synaptic ATP-sensitive $\mathrm{K}^{+}$channels in substantia nigra. Biochem Biophys Res Commun 174:909-914.

Henry P, Escande D (1994) Do potassium channel openers compete with ATP to activate ATP sensitive potassium channels? Cardiovasc Res 28:754-759.

Hicks GA, Henderson G (1992) Lack of evidence for coupling of the dopamine $\mathrm{D}_{2}$ receptor to an adenosine triphosphate-sensitive potassium (ATP-K ${ }^{+}$) channel in dopaminergic neurones of the rat substantia nigra. Neurosci Lett 141:213-217.

Hicks GA, Hudson AL, Henderson G (1994) Localization of high af finity $\left[{ }^{3} \mathrm{H}\right]$ glibenclamide binding sites within the substantia nigra zona reticulata of the rat brain. Neuroscience 61:285-292.

Jiang C, Haddad FJ, Sigworth GG (1994) Oxygen deprivation activales and ATP-inhibitable $\mathbf{K}^{+}$channel in substantia nigra neurons. I Nenrosci 14:5590-5602.

Johnson SW, North RA (1992) Two types of neurone in the rat ventral tegmental area and their synaptic inputs. J Physiol (Lond) 450:455 468.

Lacey MG (1993) Neurotransmitter receptors and ionic conductances regulating the activity of neurones in substantia nigra pars compacta and ventral tegmental area. Prog Brain Res 99:251-276.

Lacey MG, Mercuri NB, North RA (1988) On the potassium conductance increase activated by $\mathrm{GABA}_{\mathrm{B}}$ and dopamine $\mathrm{D} 2$ receptors in rat substantia nigra neurones. J Physiol (Lond) 401:437-453.

Lacey MG, Mercuri NB, North RA (1989) Two cell types in rat substantia nigra zona compacta distinguished by membrane properties and the actions of dopamine and opioids. J Neurosci 9:1233-1241.

Mercuri NB, Bonci A, Johnson SW, Stratta F, Calabresi P, Bernardi G (1994) Effects of anoxia on rat midbrain dopamine neurons. J Neurophysiol 71:1165-1173.

Miller RJ (1990) Glucose-regulated potassium channels are sweet news for neurobiologists. Trends Neurosci 13:197-199.

Mourre C, Ben-Ari Y, Bernardi H, Fosset M, Lazdunski M (1989) Antidiabetic sulfonylureas: localization of binding sites in the brain and effects on the hyperpolarization induced by anoxia in hippocampal slices. Brain Res 486:159-164.

Murphy KPSJ, Greentield SA (1992) Neuronal selectivity of AIP-sensitive potassium channels in guinea-pig substantia nigra revealed by responses to anoxia. J Physiol (Lond) 453:167-183.

Politi DM, Rogawski MA (1991) Glyburide-sensitive $\mathrm{K}^{+}$channels in cultured rat hippocampal neurons: activation by cromakalim and energy-depleting conditions. Mol Pharmacol 40:308-315.

Röper J, Ashcroft FM (1993) Reduced internal ATP concentrations and mitochondrial inhibition activate $\mathrm{K}^{+}$-ATP channels in isolated dopaminergic substantia nigra neurones from the rat. J Physiol (Lond) 473:32P.

Röper J, Hainsworth AH, Ashcroft FM (1990a) Tolbutamide reverses hypoglycaemia-induced hypcrpolarization in guinea-pig isolated substantia nigra neurones. J Physiol (Lond) 426:68P.

Röper J, Hainsworth AH, Ashcroft FM (1990b) ATP-sensitive K channels in guinea-pig isolated substantia nigra neurones are modulated by cellular metabolism. J Physiol (Lond) 430:130P.

Röper J, Hainsworth AH, Ashcroft FM (1990c) Tolbutamide reverses membrane hyperpolarisation induced by activation of $\mathrm{D} 2$ receptors and $\mathrm{GABA}_{\mathrm{B}}$ receptors in isolated substantia nigra neurones. Pfluegers Arch 416:473-475.

Schmid Antomarchi H, Amoroso S, Fosset M, Lazdunski M (1990) K $\mathrm{K}^{+}$ channel openers activate brain sulfonylurea-sensitive $\mathrm{K}^{+}$channels and block neurosecretion. Proc Natl Acad Sci USA 87:3489-3492.

Schultz W (1982) Depletion of dopamine in the striatum as an experimental model of Parkinsonism: direct effects and adaptive mechanisms. Prog Neurobiol 18:121-166.

Schwanstecher C, Panten U (1993) Tolbutamide-sensitive and diazoxide-sensitive $\mathrm{K}^{+}$channel in neurons of substantia nigra pars reticulata. Naunyn Schmicdebergs Arch Pharmacol 348:113-117.

Sellers AJ, Boden PR, Ashford MLJ (1992) Lack of effect of potassium channel openers on ATP-modulated potassium channels recorded from rat ventromedial hypothalanic neuromes. Br J Planmacol 107: 1068-1074.

Stanford IM, Lacey MG (1993) Dopamine neurones in rat substantia nigra pars compacta have ATP-sensitive potassium channels. Soc Neurosci Abstr 19:705.

Stuart GJ, Dodt HU, Sakmann B (1993) Patch-clamp recordings from the soma and dendrites of neurons in brain slices using infrared video microscopy. Pfluegers Arch 423:511-518.

Yung WH, Häusser MA, Jack JJB (1991) Electrophysiology of dopaminergic and non-dopaminergic neurones of the guinea-pig substantia nigra pars compacta in vitro. J Physiol (Lond) 436:643-668.

Zhang L, Bonev AD, Nelson MT, Mawe GM (1994) Activation of ATP-sensitive potassium currents in guinea-pig gall-bladder smooth muscle by the neuropeptide CGRP. J Physiol (Lond) 478:483-491.

Zini S, Ben-Ari Y, Ashford MLJ (1991) Characterization of sulfony lurea receptors and the action of potassium channel openers on cholinergic neurotransmission in guinea pig isolated small intestine. J Pharmacol Exp Ther 259:566-573. 